\title{
Administration of Bovine Somatotropin in Early Lactation: A Meta- Analysis of Production Responses by Multiparous Holstein Cows ${ }^{1}$
}

\author{
M. Carriquiry, ${ }^{2}$ W. J. Weber, and B. A. Crooker ${ }^{3}$ \\ Department of Animal Science, University of Minnesota, St. Paul 55108
}

\begin{abstract}
A meta-analysis was conducted to assess production responses before $90 \mathrm{~d}$ in milk (DIM) when bovine somatotropin (bST) administration was initiated between 5 and 35 DIM. The database was developed from 13 studies of multiparous cows that were published between 1985 and 2006 and from an unpublished study that complied with the study selection criteria. The database included results from 842 cows and provided 50 treatment means for the effect of bST on 3.5\% fat-corrected milk (FCM) in early lactation. Effects of bST were investigated using mixed model procedures that included fixed (intercept and slope) and random (intercept and slope) effects for independent variables. Yields of milk $(38.6 \pm 1.3 \mathrm{~kg} / \mathrm{d})$ and FCM $(37.6 \pm 1.6 \mathrm{~kg} / \mathrm{d})$ by control cows before $90 \mathrm{DIM}$ were increased by $2.6 \pm 0.8$ and 3.2 $\pm 0.6 \mathrm{~kg} / \mathrm{d}$ by bST administration. Fat content in milk from bST-treated cows was $0.31 \pm 0.10$ percentage units greater than that from control cows $(3.46 \pm 0.13 \%)$ but milk protein content $(2.95 \pm 0.03 \%)$ was not altered by bST. Milk fat $(1.39 \pm 0.10 \mathrm{~kg} / \mathrm{d})$ and protein $(1.15 \pm 0.04$ $\mathrm{kg} / \mathrm{d}$ ) yields by controls were increased $0.16 \pm 0.03$ and $0.07 \pm 0.03 \mathrm{~kg} / \mathrm{d}$ by bST, respectively. Dry matter intake and body weight loss were not altered by bST before 90 DIM, but duration of negative energy balance was prolonged and overall energy balance during this interval reduced when cows were treated with bST. Results are consistent with the premise that bST-treated cows partition nutrients and energy toward milk synthesis for a longer duration and thus likely need a longer interval to replenish their body reserves than cows not treated with bST. Production responses to bST were not altered when cows consumed typical early-lactation
\end{abstract}

Received November 7, 2007.

Accepted March 7, 2008.

${ }^{1}$ This work was supported in part by a Doctoral Dissertation Research Grant from the Graduate School at the University of Minnesota and by a Hueg-Harrison Fellowship awarded to M. Carriquiry and by the University of Minnesota Agricultural Experiment Station (project number 16-46).

${ }^{2}$ Current address: Facultad de Agronomia, Avda. Garzón 810, 12900 Montevideo, Uruguay.

${ }^{3}$ Corresponding author: crook001@umn.edu diets supplemented with fat except that supplemental fat tended to decrease the magnitude of the effect of bST on milk fat content and decreased the effect of bST on fat and protein yield. Yield of FCM increased curvilinearly with the amount of bST administered. Results indicate that initiation of bST administration to cows before 35 DIM increased FCM yield but the response was at the low end of that typically observed when bST administration is initiated in wk 9 of lactation.

Key words: bovine somatotropin, early lactation, production, meta-analysis

\section{INTRODUCTION}

Bovine somatotropin plays a clear and powerful role in the homeorhetic coordination of multiple metabolic alterations that occur in several tissues and are required for the cow to adapt successfully to the metabolic demand imposed by the onset of copious milk production (Bell and Bauman, 1997; Bauman, 1999). Reports from designed studies (Bauman et al., 1989; Hartnell et al., 1991; Stanisiewski et al., 1994), reviews (Etherton and Bauman, 1998; Dohoo et al., 2003), and commercial use (Bauman et al., 1999; Collier et al., 2001) demonstrate that administration of bST to cows in mid or late lactation increased FCM yield 3 to $6 \mathrm{~kg} /$ $\mathrm{d}$, improved productive efficiency by partitioning nutrients toward the mammary gland for increased milk synthesis and did not alter milk composition (fat, protein, and lactose) when cows consumed sufficient nutrients and energy.

One of the most significant direct effects of bST binding to its receptor is stimulation of IGF-I synthesis (predominantly in the liver) because plasma IGF-I mediates bST actions in several tissues including the mammary gland (Cohick, 1998). Commercial use of bST for lactating cows is approved for treatment initiation in wk 9 of lactation. This is due, in part, to results that indicate milk yield response was greater and likely more economical when treatment was initiated after peak milk yield or when cows were in positive energy and nutrient balance (Chilliard, 1989; Stanisiewski et al., 1992; Bauman and Vernon, 1993). In early lactation 
when cows are in negative energy and nutrient balance, expression of the liver-specific isoform of the growth hormone receptor (GHR)-1A and GHR protein is reduced (Radcliff et al., 2003, 2006), which likely contributes to the reduced circulating concentrations of IGFI in early lactation (Radcliff et al., 2006) and could help explain why milk and IGF-I (Vicini et al., 1991; McGuire et al., 1992) responses to bST are greater after cows regain positive energy and nutrient status. However, hepatic expression of GHR-1A appears to return to prepartum values by 21 DIM in well-fed cows (Radcliff et al., 2006), and bST administration can increase circulating IGF-I concentrations soon after the energy balance nadir (Weber, 1997; Carriquiry, 2006). Although bST administration in early lactation has resulted in little or no increase in milk yield (Elvinger et al., 1988; Zhao et al., 1992) and milk response has been characterized as small or negligible when bST is administered before peak milk yield (Bauman and Vernon, 1993), initiation of bST administration at 14 to 21 DIM has increased milk yield by more than $3 \mathrm{~kg} / \mathrm{d}$ in early lactation (Richard et al., 1985; Weber, 1997; Moallem et al., 2000; Carriquiry, 2006). These results prompted us to conduct a meta-analysis to assess effects of bST administration to cows in early lactation.

Meta-analysis procedures use statistical methods to combine data from independent studies for a quantitative analysis. These procedures are particularly useful when there is a conflict in the results reported in the literature and when the small sample size of individual studies limits statistical power of the individual studies to detect differences (Wang and Bushman, 1999; Normand, 1999; St-Pierre, 2001). The objective of this study was to quantitatively and statistically assess the effects of initiation of bST administration between 5 and 35 DIM on production responses before 90 DIM.

\section{MATERIALS AND METHODS}

\section{Database}

Publications that reported effects of initiation of bST administration before 35 DIM on performance before 90 DIM were identified through a computerized literature search (CAB Abstracts, AGRICOLA, and PubMed) and review of citations in publications identified by the search. To be included in the analysis, publications had to be in English and describe studies that 1) randomized cows to treatment, 2) used only multiparous Holstein cows, 3) initiated administration of bST before 35 DIM, and 4) provided sufficient data to determine 3.5\% FCM response before 90 DIM. The search identified 12 publications (Table 1) that fit these criteria. One publication (Hansen et al., 1994) reported results for 2 consecutive lactations and considered each lactation as a separate study. Some cows used by Burton et al. (1990) were used in their subsequent lactation by McBride et al. (1990). Results from these 2 publications were treated as separate studies. Results from an unpublished study conducted by our lab (B. A. Crooker, personal communication) met the selection criteria and provided a 14th study (Table 1). The search identified 7 other studies that initiated bST administration before 35 DIM but failed to meet selection criteria because reported data were not sufficient to determine 3.5\% FCM response before 90 DIM, were means from groups composed of primiparous and multiparous cows or composed of multiple breeds, or some combination of these factors (Elvinger et al., 1988; Lormore et al., 1990; Austin et al., 1991; McGuffey et al., 1991; Zhao et al., 1992; Chalupa et al., 1996; Moallem et al., 1999).

\section{Extracted Data}

Nine outcome variables or the information needed to compute them were reported in most of these studies and were selected for evaluation in this meta-analysis (Table 1). Data (mean value and its standard error) extracted from the studies were milk and 3.5\% FCM yields $(\mathrm{kg} / \mathrm{d})$, protein and fat content $(\%)$, protein and fat yields $(\mathrm{kg} / \mathrm{d}), \mathrm{DMI}(\mathrm{kg} / \mathrm{d}), \mathrm{BW}$ change $(\mathrm{kg} / \mathrm{d})$, and energy balance (EB, Mcal of $\mathrm{NE}_{\mathrm{L}} / \mathrm{d}$ ). Some early lactation response data were not reported specifically but were extracted from figures (Hansen et al., 1994; Moallem et al., 1997, 2000). All extracted values represented either means or differences from initiation ( 5 to 35 DIM) to end (before $90 \mathrm{DIM}$ ) of the bST evaluation interval (Table 1). For any study, if the number of cows per treatment was not balanced, the average number of cows per treatment was reported (Table 1). However, the actual number of cows per treatment was used in the analysis.

In addition to the outcome variables, the number of treatment groups, number of cows per treatment group, DIM at initiation of bST treatment, duration of treatment, delivery vehicle formulation (daily or sustained release injections), amount of bST administered, interval between injections, and type of diet were reported (Table 1). Although the overall effect of delivery vehicle formulation was assessed, extraction of study data as means per interval of measurement rather than as day within injection interval prevented an evaluation of the saw-tooth milk response plots (Bauman et al., 1989; Eppard et al., 1991) obtained frequently with sustained release formulations of bST against the usually more stable milk response plots obtained with daily administration of bST (Stanisiewski et al., 1992, 1994). Studies $(\mathrm{n}=6)$ that evaluated more than one nonzero dose of bST were classified as dose-response studies. Some 
Table 1. Studies included in the meta-analysis to determine effects of initiation of bST administration before 35 DIM on production responses before 90 DIM

\begin{tabular}{|c|c|c|c|c|c|c|c|c|c|c|c|c|c|c|}
\hline \multirow[b]{2}{*}{ Study } & \multirow[b]{2}{*}{ Groups $^{1}$} & \multirow[b]{2}{*}{ Cows $^{2}$} & \multicolumn{3}{|c|}{ bST administration } & \multirow{2}{*}{$\begin{array}{c}\text { Amount } \\
\text { administered }^{3} \\
(\mathrm{mg} / \mathrm{d})\end{array}$} & \multirow[b]{2}{*}{ Diet $^{4}$} & \multicolumn{7}{|c|}{ Study contributed to analysis of the variable } \\
\hline & & & $\begin{array}{l}\text { Initiation } \\
\text { (DIM) }\end{array}$ & $\begin{array}{l}\text { Duration } \\
\text { (d) }\end{array}$ & Form $^{5}$ & & & FCM & Milk & $\begin{array}{l}\text { Fat }^{6} \\
(\% / k g)\end{array}$ & $\begin{array}{c}\text { Protein }^{6} \\
(\% / k g)\end{array}$ & DMI & BW & $\mathrm{EB}^{7}$ \\
\hline Richard et al. (1985) & 2 & 4 & 20 & 10 & $\mathrm{D}$ & 0,50 & $\mathrm{~T}$ & Yes & Yes & Yes/Yes & Yes/Yes & Yes & No & Yes \\
\hline Burton et al. (1990) & 4 & 9 & 28 to 35 & 63 & $\mathrm{D}$ & $0,10.3,20.6$, or 41.2 & $\mathrm{~T}$ & Yes & No & No/No & Yes/No & Yes & No & No \\
\hline McBride et al. (1990) & 3 & 14 & 28 to 35 & 63 & $\mathrm{D}$ & $0,10.3$, or 20.6 & $\mathrm{~T}$ & Yes & Yes & No/No & No/No & No & No & No \\
\hline Schneider et al. (1990) & 4 & 4 & 14 & 56 & $\mathrm{D}$ & 0 or 41.2 & $\mathrm{~T} / \mathrm{SF}$ & Yes & Yes & Yes/No & Yes/No & Yes & Yes & Yes \\
\hline Stanisiewski et al. (1992) & 3 & 42 & 14 & 46 & $\mathrm{D}$ & 0,5, or 14 & $\mathrm{~T}$ & Yes & No & No/No & No/No & No & No & No \\
\hline de Boer et al. (1991) & 4 & 4 & 25 to 30 & 63 & $\mathrm{D}$ & 0 or 20.6 & $\mathrm{~T} / \mathrm{SP}$ & Yes & Yes & Yes/Yes & Yes/Yes & Yes & Yes & No \\
\hline Hansen et al. (1994) (yr 1) & 4 & 55 & 28 to 35 & 42 & $\mathrm{D}$ & $0,5.15,10.3$, or 16.5 & $\mathrm{~T}$ & Yes & No & No/No & No/No & No & No & No \\
\hline Hansen et al. (1994) (yr 2) & 4 & 29 & 28 to 35 & 42 & $\mathrm{D}$ & $0,5.15,10.3$, or 16.5 & $\mathrm{~T}$ & Yes & No & No/No & No/No & No & No & No \\
\hline Moallem et al. (1997) & 4 & 12 & 10 & 55 & $\mathrm{SR}^{8}$ & 0 or 35.7 & $\mathrm{~T} / \mathrm{SF}$ & Yes & Yes & Yes/Yes & Yes/Yes & No & No & No \\
\hline Weber (1997) & 6 & 12 & 14 & 49 & $\mathrm{D}$ & 0,5, or 14 & $\mathrm{~T} / \mathrm{SF}$ & Yes & Yes & Yes/Yes & Yes/Yes & Yes & Yes & Yes \\
\hline Santos et al. (1999) & 4 & 8 & 5 & 45 & $\mathrm{SR}^{8}$ & 0 or 35.7 & $\mathrm{~T}^{9}$ & Yes & Yes & Yes/Yes & Yes/Yes & Yes & No & No \\
\hline Moallem et al. (2000) & 2 & 13 & 10 & 55 & $\mathrm{SR}^{8}$ & 0 or 35.7 & $\mathrm{~T}$ & Yes & Yes & Yes/Yes & Yes/Yes & Yes & No & No \\
\hline Carriquiry (2006) & 4 & 15 & 12 & 56 & $\mathrm{SR}^{10}$ & 0 or 50 & $\mathrm{~T} / \mathrm{SF}$ & Yes & Yes & Yes/Yes & Yes/Yes & Yes & Yes & Yes \\
\hline Crooker (unpublished) & 2 & 12 & 14 & 49 & $\mathrm{D}$ & 0 or 14 & $\mathrm{~T}$ & Yes & Yes & Yes/Yes & Yes/Yes & Yes & Yes & Yes \\
\hline
\end{tabular}

${ }^{1}$ Number of treatment groups per study with a maximum of 50 groups for the meta-analysis of any variable.

${ }^{2}$ Number of cows per treatment group. If the number of cows per treatment was not balanced, the average number of cows per treatment was reported. The actual number of cows per treatment was used in the analysis.

${ }^{3}$ Specific dose studies are those that evaluated more than one nonzero dose of bST.

${ }^{4}$ Typical early lactation $\operatorname{diet}(\mathrm{T})$ or the same diet supplemented with fat (SF) or protein (SP).

${ }^{5}$ Administered in a daily (D) or a sustained release (SR) delivery vehicle formulation.

${ }^{6}$ Milk component content $(\%)$ and yield $(\mathrm{kg} / \mathrm{d})$.

${ }^{7} \mathrm{~EB}=$ energy balance.

$8500 \mathrm{mg}$ every $14 \mathrm{~d}$ and assuming a linear payout.

${ }^{9}$ Two diets with different carbohydrate sources (steam-rolled corn and steam-flaked sorghum).

${ }^{10} 500 \mathrm{mg}$ every $10 \mathrm{~d}$ and assuming a linear payout. 
studies examined effects of supplemental dietary fat $(\mathrm{n}=4)$, supplemental dietary protein $(\mathrm{n}=1)$, or source of dietary carbohydrate $(\mathrm{n}=1)$ in balanced factorial arrangements of dietary treatment and bST administration.

\section{Statistical Analysis}

Effect of bST administration and amount administered ( 0 to $50 \mathrm{mg} / \mathrm{d})$ on outcome variables were investigated using mixed model procedures (PROC MIXED; SAS Institute, 2001) following methodology described by St-Pierre (2001). The model included both fixed (intercept and slope) and random (intercept and slope) effects for independent variables. The intercept and slope of the fixed effect in the mixed model represent a mean intercept and a mean slope for the response to bST administration. The intercept and slope of the random effects in the mixed model estimate the response for each specific study. The random study effect represents the variance among studies that is not accounted for by other variables in the model that contribute significantly to the regression analysis (St-Pierre, 2001). The early lactation diets used in the studies were identified as either typical or supplemented with fat or protein, and diet was included in the analysis as a fixed, discrete independent variable. The interaction of diet with bST was included to assess homogeneity of the slopes among the different diets. Data were weighted by the reciprocal of the standard error of each mean (St-Pierre, 2001) to account for heterogeneous errors among studies. Linear and quadratic effects of the amount of bST administered ( 0 to $50 \mathrm{mg} / \mathrm{d}$ for daily and for sustained release formulations if a linear payout is assumed) were evaluated using data from all 14 studies and from the 6 dose-response studies.

Magnitude of the bST effect was calculated as the standardized difference between bST and control treatment means (Normand, 1999). Effects of delivery vehicle formulation (daily vs. sustained release injections), amount administered ( 0 to $50 \mathrm{mg} / \mathrm{d}$ ), DIM at initiation of treatment ( 5 to $35 \mathrm{DIM}$ ), and duration (10 to $63 \mathrm{~d}$ ) of treatment, and number of animals (4 to 55 cows/ treatment) on the effect of bST were evaluated using mixed model procedures (PROC MIXED; SAS Institute, 2001). Linear regression coefficients were estimated (PROC REG; SAS Institute, 2001). Scatter plots of treatment effects from individual studies vs. their standard error were used to assess the presence of publication bias (Normand, 1999; Sutton et al., 2000).

\section{RESULTS}

\section{Milk Yield and Composition}

Descriptive summary statistics for the 9 extracted variables (Table 2) indicate that data from these 14 studies are representative of multiparous Holsteins in early lactation. Administration of bST increased FCM yield at least numerically in 27 of the 29 comparisons with controls (Figure 1). Data extracted from these studies evaluated effects of bST administration from before 35 DIM to before 77 DIM ( $\mathrm{n}=11$ studies, 61.9 $\pm 3.8 \mathrm{DIM})$ or before $98 \mathrm{DIM}(\mathrm{n}=3$ studies, $93.1 \pm$ 1.3 DIM). For all 14 studies, the end of the evaluation interval was $68.6 \pm 4.6 \mathrm{DIM}$. Inclusion of the 3 studies that extended the evaluation period to 93 DIM did not appear to alter interpretation of the effects of bST. Meta-analysis of the data from these 14 studies (50 groups, 842 cows) indicated initiation of bST administration before 35 DIM increased $(P<0.001) 3.5 \%$ FCM yield by $3.2 \pm 0.6 \mathrm{~kg} / \mathrm{d}$ before 90 DIM (Table 3 and Figure 2). This represents an $8.5 \%$ increase as FCM yield by the control groups was $37.6 \pm 1.6 \mathrm{~kg} / \mathrm{d}$. There was considerable variation among studies for the effect of bST on FCM yield $(P<0.001)$ but there was no effect of group size, DIM at initiation of treatment, duration of treatment, or delivery vehicle formulation $(P>$ 0.38) on magnitude of the FCM response to bST (Table 4). Magnitude of the FCM response increased linearly $\left(\mathrm{y}=38.1+0.13 \mathrm{x} ; \mathrm{R}^{2}=0.15 ; P=0.005\right)$ but not quadratically $(P=0.98)$ as the amount of bST administered increased from 0 to $50 \mathrm{mg} / \mathrm{d}$ (Table 4). Magnitude of the FCM response in the 6 dose response studies (24 groups, 612 cows) increased linearly $(\mathrm{y}=38.4+0.16 \mathrm{x}$; $\left.\mathrm{R}^{2}=0.64 ; P=0.009\right)$ and quadratically $(\mathrm{y}=38.0+0.27 \mathrm{x}$ $\left.-0.004 \mathrm{x}^{2} ; \mathrm{R}^{2}=0.36 ; P=0.046\right)$ as dose of bST increased from 0 to $41.2 \mathrm{mg} / \mathrm{d}$.

Ten of the studies (35 groups, 344 cows) reported that milk yield and bST increased $(P<0.005)$ milk yield $2.6 \pm 0.8 \mathrm{~kg} / \mathrm{d}$ during the treatment interval (Table 3 ). Although there was a strong effect of study $(P=0.001)$, group size, DIM at initiation of treatment, duration of treatment, and delivery vehicle formulation of bST did not affect $(P>0.67)$ milk yield response to bST (Table 4). When data from all 10 studies that reported milk yield were evaluated, milk yield response increased in a linear $\left(\mathrm{y}=38.9+0.08 \mathrm{x} ; \mathrm{R}^{2}=0.16 ; P=0.008\right)$ but not a quadratic $(P>0.24)$ manner as the amount of bST administered increased from 0 to $50 \mathrm{mg} / \mathrm{d}$. When data from the 2 dose response studies were evaluated, there was no linear $(P>0.27)$ or quadratic $(P>0.60)$ effect of dose on milk yield response.

The effect of initiation of bST administration between 5 and 35 DIM on milk composition was examined using data from 9 studies (32 groups, 302 cows) that reported milk fat content and 10 studies (36 groups, 338 cows) that reported milk protein content. Only one of these studies (Weber, 1997) was a dose-response study. Fat content of milk from the control groups was $3.46 \pm$ 
Table 2. Summary statistics of studies included in the meta-analysis to determine effects of initiation of bST administration before 35 DIM on production response before 90 DIM

\begin{tabular}{lcccccccc}
\hline & \multicolumn{3}{c}{ Total $^{1}$} & & \multicolumn{4}{c}{ Variable } \\
\cline { 2 - 3 } Variable & Studies & Groups & Cows & & Mean & SD & Minimum & Maximum \\
\hline 3.5\% FCM, kg/d & 14 & 50 & 842 & & 39.9 & 5.7 & 29.9 & 55.5 \\
Milk, kg/d & 10 & 35 & 344 & & 40.3 & 4.6 & 32.0 & 49.4 \\
Fat, \% & 9 & 32 & 302 & & 3.56 & 0.49 & 2.76 & 4.84 \\
Protein, \% & 10 & 36 & 338 & & 2.94 & 0.10 & 2.80 & 3.22 \\
Fat, kg/d & 8 & 28 & 286 & & 1.46 & 0.31 & 0.95 & 2.12 \\
Protein, kg/d & 8 & 28 & 286 & & 1.20 & 0.12 & 0.96 & 1.39 \\
DMI, kg/d & 9 & 32 & 290 & 21.7 & 1.9 & 18.2 & 25.8 \\
BW change, kg/d & 5 & 20 & 188 & -0.12 & 0.37 & -0.63 & 1.01 \\
Energy balance, Mcal of $\mathrm{NE}_{\mathrm{L}} / \mathrm{d}$ & 5 & 18 & 180 & -3.62 & 5.00 & -10.70 & 7.08 \\
\hline
\end{tabular}

${ }^{1}$ Number of studies, treatment groups, and cows that contributed to the analysis.

0.13\%. Initiation of bST administration before $35 \mathrm{DIM}$ increased $(P=0.011)$ milk fat content by $0.31 \pm 0.10$ percentage units $(9 \%$ increase) but did not modify $(P=$ 0.70 ) percent milk protein (Table 3). Effects of bST on milk fat and protein content were not altered $(P>0.45)$ by group size, DIM at initiation of treatment, or delivery vehicle formulation of bST (Table 4). Duration of treatment decreased $(P=0.040)$ the effect of bST on milk fat content but did not affect $(P>0.99)$ milk protein content. This association between bST effect on milk fat content and duration of treatment was due to one study (Richard et al., 1985) because removal of this study from the analysis eliminated the effect. Milk fat content increased linearly $\left(y=3.36+0.013 x ; R^{2}=0.57\right.$; $P=0.0045)$ but not quadratically ( $\mathrm{y}=3.48-0.03 \mathrm{x}+$ $\left.0.001 \mathrm{x}^{2} ; \mathrm{R}^{2}=0.51 ; P=0.10\right)$ as the amount of $\mathrm{bST}$
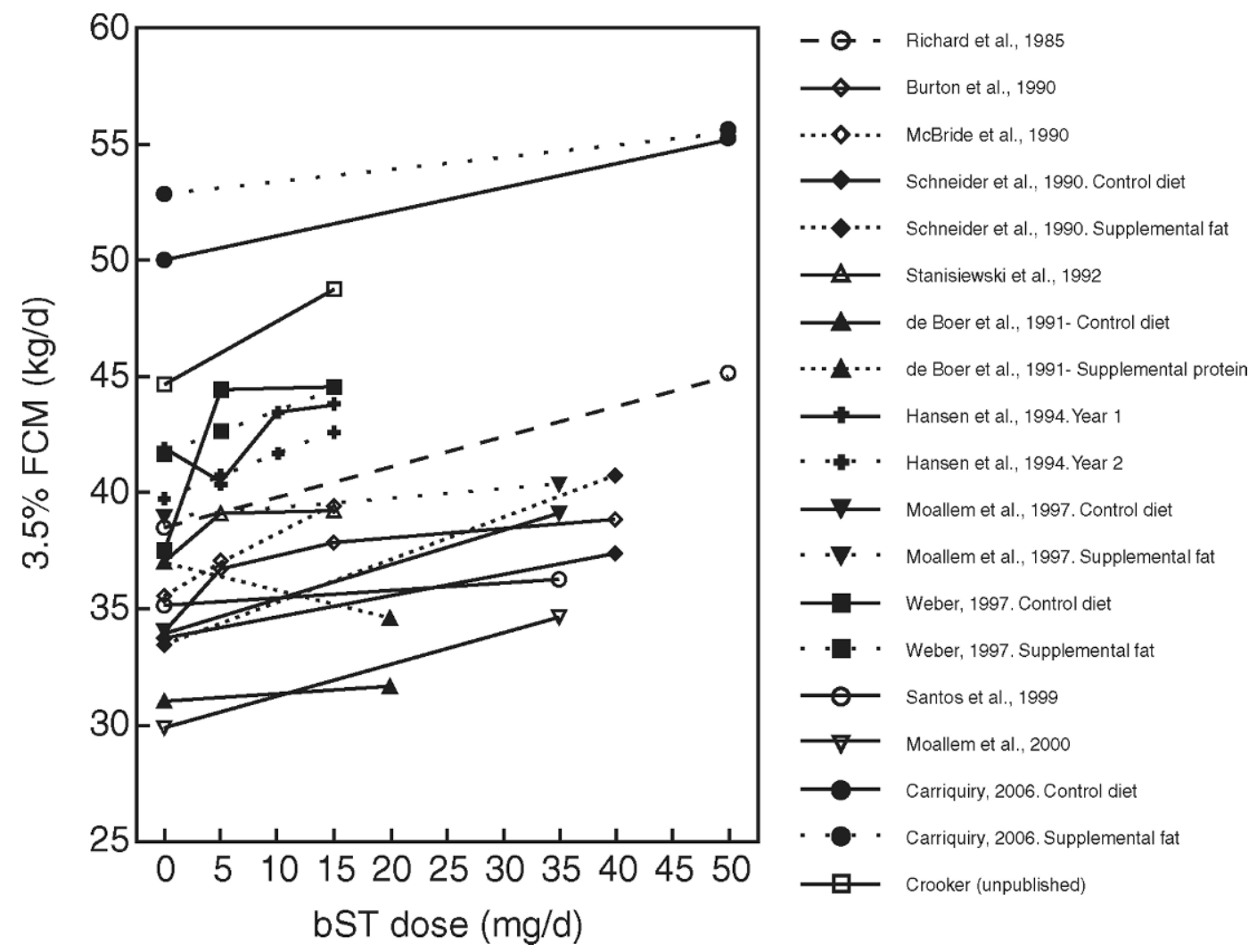

Figure 1. Effect of initiation of bST administration before 35 DIM on 3.5\% FCM response before 90 DIM. The data points represent treatment means extracted from studies used in the meta-analysis. When administered as a sustained release formulation, the daily dose was assumed to be equivalent to that expected from a linear payout of bST. 
Table 3. Effect of initiation of bST administration before 35 DIM on production response before 90 DIM

\begin{tabular}{|c|c|c|c|c|c|c|}
\hline \multirow[b]{2}{*}{ Variable } & \multirow[b]{2}{*}{ Groups $^{1}$} & \multicolumn{2}{|c|}{ Control } & \multicolumn{3}{|c|}{ Response to bST } \\
\hline & & Mean & $\mathrm{SE}$ & Mean & $\mathrm{SE}$ & $P$ \\
\hline $3.5 \%$ FCM, kg/d & 50 & 37.6 & 1.6 & 3.2 & 0.6 & 0.001 \\
\hline Milk, kg/d & 35 & 38.6 & 1.3 & 2.6 & 0.8 & 0.009 \\
\hline Fat, $\%$ & 32 & 3.46 & 0.13 & 0.31 & 0.10 & 0.015 \\
\hline Protein, \% & 36 & 2.95 & 0.03 & 0.01 & 0.03 & 0.695 \\
\hline Fat, kg/d & 28 & 1.39 & 0.10 & 0.16 & 0.03 & 0.002 \\
\hline Protein, kg/d & 28 & 1.15 & 0.04 & 0.07 & 0.03 & 0.049 \\
\hline DMI, kg/d & 32 & 21.8 & 0.63 & -0.14 & 0.20 & 0.757 \\
\hline BW change, kg/d & 20 & -0.09 & 0.13 & -0.10 & 0.13 & 0.507 \\
\hline Energy balance, Mcal of $\mathrm{NE}_{\mathrm{L}} / \mathrm{d}$ & 18 & -2.75 & 2.40 & -3.14 & 0.89 & 0.025 \\
\hline
\end{tabular}

${ }^{1}$ Number of treatment groups (total of control and bST) that contributed to the analysis.

administered increased. Amount of bST administered did not alter $(P>0.19)$ milk protein content.

Eight of the studies (28 groups, 286 cows) reported milk fat and protein yields but only one study (Weber, 1997) was a dose-response study. The meta-analysis indicated that initiation of bST administration between 5 and 35 DIM increased milk fat $(P=0.002)$ and protein $(P=0.049)$ yields (11.5 and $6 \%$, respectively; Table 3$)$ before 90 DIM. Group size, DIM at initiation of treatment, and delivery vehicle formulation of bST administered did not alter $(P>0.42)$ the response of milk fat or protein yield to bST (Table 4). Duration of treatment tended to decrease the effect of bST on fat $(P=0.083)$ and protein $(P=0.09)$ yields. However, this association was due to one short (10-d) study (Richard et al., 1985) because its removal from the analysis eliminated the impact $(P=0.70)$ of duration of treatment on the effect of bST on fat and protein yields. Yield of milk fat in-

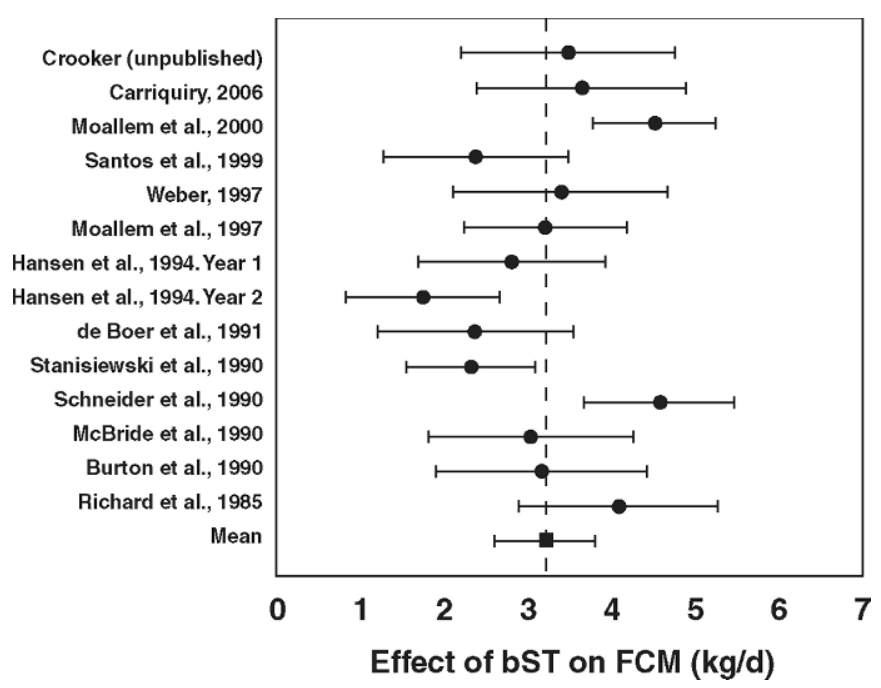

Figure 2. Forest plot of effects of bST on 3.5\% FCM. Administration of bST was initiated before 35 DIM and responses evaluated before 90 DIM. Estimates were obtained from mixed model analysis. creased linearly $\left(\mathrm{y}=1.40+0.005 \mathrm{x} ; \mathrm{R}^{2}=0.17 ; P=0.003\right)$ but not quadratically $(P>0.84)$ as the amount of bST administered increased. Yield of protein was not affected by dose of bST $(P>0.17)$.

\section{$D M I, B W$, and $E B$}

Initiation of bST administration between 5 and 35 DIM did not modify $(P>0.76)$ DMI before 90 DIM (9 studies, 32 groups, 290 cows; Table 3, Figure 3). There was an effect of study $(P=0.01)$ on DMI, but group size, DIM at initiation of treatment and duration of treatment, and delivery vehicle formulation of bST were not associated $(P>0.27)$ with variation in the DMI response to bST (Table 4). Dry matter intake increased quadratically $\left(\mathrm{y}=21.8+0.07 \mathrm{x}-0.002 \mathrm{x}^{2} ; \mathrm{R}^{2}=0.68 ; P\right.$ $<0.032)$ but not linearly $(P>0.50)$ in response to bST dose when data from all studies that reported DMI were evaluated. A similar quadratic response $(\mathrm{y}=20.7+$ $\left.0.14 \mathrm{x}-0.003 \mathrm{x}^{2} ; \mathrm{R}^{2}=0.94 ; P=0.020\right)$ was obtained when only the specific dose-response studies $(\mathrm{n}=2)$ were evaluated.

Only 5 studies (20 groups, 188 cows) provided data to assess effects of bST on BW change. Results indicate administration of bST in early lactation did not affect $(P=0.51)$ BW loss before 90 DIM (Table 3). This effect of bST on BW change was consistent $(P=0.96)$ among studies and was not affected $(P>0.50)$ by group size, DIM at initiation of treatment and duration of treatment, or amount of bST administered (Table 4). Effects of delivery vehicle formulation and bST dose could not be analyzed because only one sustained release formulation study and one dose-response study evaluated effects of bST on BW change. There were no linear $(P=$ $0.33)$ or quadratic $(P=0.96)$ effects of bST on BW change.

Initiation of bST administration between 5 and 35 DIM reduced EB (3.14 $\pm 0.9 \mathrm{Mcal} / \mathrm{d}, P=0.025)$ before 90 DIM (5 studies, 18 groups, 180 cows; Table 3 ). There was an effect of study on the effect of bST on EB $(P=$ 
Table 4. Effect of study design on the effects of initiation of bST administration before 35 DIM on production responses before 90 DIM

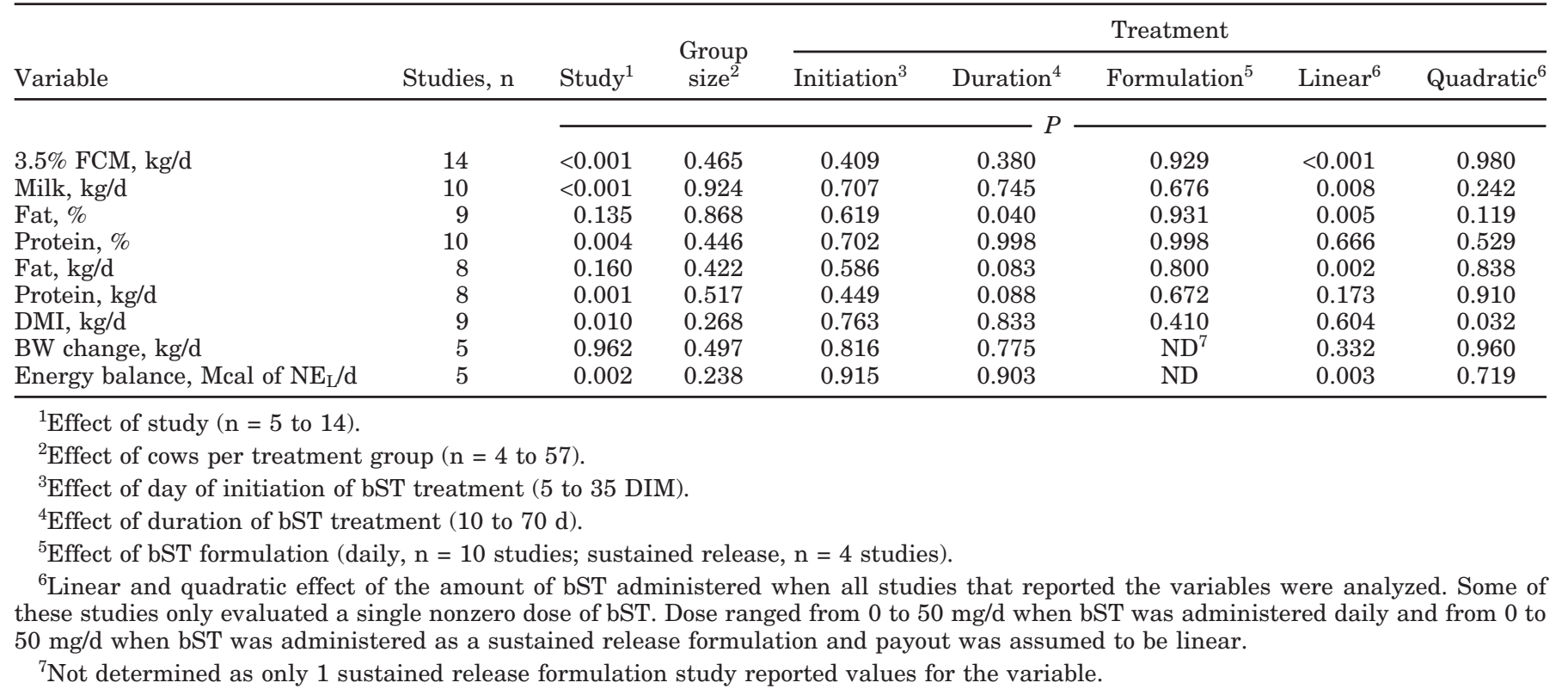

0.002), but group size and DIM at initiation and duration of treatment did not influence $(P>0.24)$ this effect (Table 4). The effect of bST delivery vehicle formulation on EB could not be analyzed because only 1 of the 5 studies used a sustained release formulation. A linear decrease $\left(\mathrm{y}=-2.72-0.10 \mathrm{x} ; \mathrm{R}^{2}=0.82 ; P=0.003\right)$ but no quadratic effect $(P>0.72)$ on EB occurred as the amount of bST administered increased.

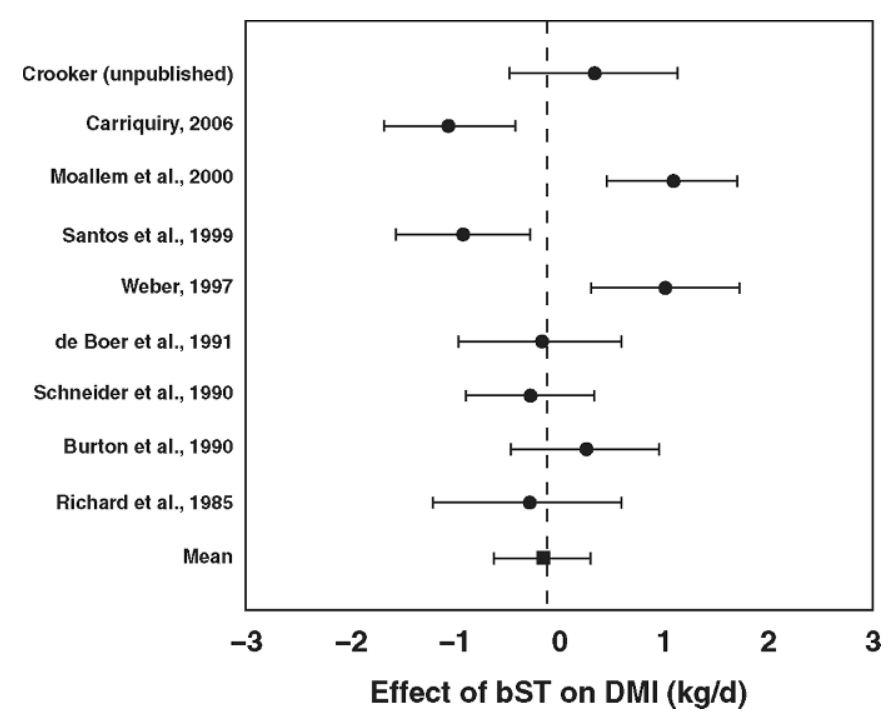

Figure 3. Forest plot of effects of bST on DMI. Administration of bST was initiated before 35 DIM and responses evaluated before 90 DIM. Estimates were obtained from mixed model analysis.

\section{Supplemental Dietary Fat and Protein}

Supplementation of early lactation diets with fat or protein increased $(P<0.004)$ daily yields of FCM $(2.7$ $\pm 0.9 \mathrm{~kg} / \mathrm{d})$ and milk $(1.7 \pm 0.6 \mathrm{~kg} / \mathrm{d})$. However, $33.6 \%$ of the FCM response was due to results from the one small study (4 cows/treatment) that evaluated supplemental protein (de Boer et al., 1991) and its removal reduced the response of FCM and milk yield to $1.82 \pm$ 0.9 and $1.33 \pm 0.7 \mathrm{~kg} / \mathrm{d}$, respectively (Table 5 ). Response of FCM to bST in studies $(\mathrm{n}=4)$ that evaluated supplemental dietary fat did not differ $(P>0.57)$ from that obtained when all 14 studies were evaluated (3.2 \pm 0.7 vs. $3.3 \pm 0.6 \mathrm{~kg} / \mathrm{d}$, respectively). Supplemental dietary fat did not alter the magnitude of the FCM $(P=0.57)$ or the milk $(P=0.38)$ response to bST.

Percentage milk fat increased $(P=0.020)$ by $0.19 \pm$ 0.07 percentage units when cows were fed diets supplemented with fat. Magnitude of the bST effect on milk fat content tended $(P=0.069)$ to be reduced by $0.19 \pm$ 0.09 percentage units when cows were fed supplemental fat (Table 5). Milk fat yield increased $(P<0.001)$ by $0.21 \pm 0.02 \mathrm{~kg} / \mathrm{d}$ when cows were fed a diet supplemented with fat. When cows were fed diets supplemented with fat, magnitude of the bST effect on milk fat yield decreased $(P<0.001)$ by $0.22 \pm 0.03 \mathrm{~kg} / \mathrm{d}$ (Table $5)$. Dietary fat did not affect $(P=0.40)$ percentage milk protein or the effect $(P=0.37)$ of bST on percentage milk protein (Table 5). Supplementation of early lactation diets with fat increased $(P=0.016)$ milk protein 
Table 5. Effect of initiation of bST administration before $35 \mathrm{DIM}$ and supplemental dietary fat on production response before $90 \mathrm{DIM}^{1}$

\begin{tabular}{|c|c|c|c|c|c|c|c|c|c|}
\hline \multirow[b]{2}{*}{ Variable } & \multicolumn{3}{|c|}{$\mathrm{bST}^{2}$} & \multicolumn{3}{|c|}{ Dietary fat ${ }^{3}$} & \multicolumn{3}{|c|}{ bST $\times$ Dietary fat } \\
\hline & Mean & SE & $P$ & Mean & SE & $P$ & Mean & SE & $P$ \\
\hline $3.5 \%$ FCM, kg/d & 3.3 & 0.7 & $<0.001$ & 1.82 & 0.90 & 0.059 & 0.69 & 1.21 & 0.574 \\
\hline Milk, kg/d & 2.1 & 0.7 & 0.011 & 1.33 & 0.71 & 0.087 & 0.88 & 0.96 & 0.382 \\
\hline Fat, $\%$ & 0.39 & 0.01 & 0.003 & 0.19 & 0.07 & 0.020 & -0.19 & 0.09 & 0.069 \\
\hline Protein, \% & 0.02 & 0.03 & 0.530 & -0.03 & 0.03 & 0.402 & -0.04 & 0.04 & 0.371 \\
\hline Fat, kg/d & 0.22 & 0.03 & $<0.001$ & 0.21 & 0.02 & 0.001 & -0.22 & 0.03 & 0.001 \\
\hline Protein, kg/d & 0.07 & 0.03 & 0.039 & 0.07 & 0.02 & 0.016 & -0.09 & 0.03 & 0.024 \\
\hline DMI, kg/d & -0.19 & 0.49 & 0.707 & -0.92 & 0.50 & 0.095 & 0.23 & 0.66 & 0.739 \\
\hline BW change, $\mathrm{kg} / \mathrm{d}$ & 0.05 & 0.21 & 0.826 & -0.09 & 0.08 & 0.353 & 0.07 & 0.11 & 0.562 \\
\hline Energy balance, Mcal of $\mathrm{NE}_{\mathrm{L}} / \mathrm{d}$ & -3.32 & 0.98 & 0.027 & 0.31 & 0.68 & 0.662 & 0.49 & 0.92 & 0.611 \\
\hline
\end{tabular}

${ }^{1}$ Data are from 4 studies and each study used a factorial arrangement to compare bST (a zero dose and 1 or 2 nonzero doses) and supplemental dietary fat (2 diets, 1 with and 1 without supplemental dietary fat).

${ }^{2}$ Administered as a daily ( 2 studies) or a sustained release ( 2 studies) formulation.

${ }^{3}$ Supplemental dietary fat provided as 2.2 to $5 \%$ of dietary DM.

yield and decreased $(P=0.024)$ the effect of bST (Table 5).

Supplementation of the basal diet with fat tended $(P=0.095)$ to decrease $(0.92 \pm 0.50 \mathrm{~kg} / \mathrm{d})$ DMI but did not modify $(P=0.74)$ the effect of bST on DMI (Table $5)$. Supplementation of the basal diet with fat did not affect BW change $(P=0.35)$ or EB $(P=0.66)$ and did not modify the effect $(P>0.56)$ of bST on these variables (Table 5).

\section{Variation Among Data Sets}

Scatter plots of the effects of bST against their standard errors indicate that the analysis included data from studies that reported small and negative effects of bST and that these effects were associated with standard errors that were similar to those from other studies in the data set (Figure 4). Results from all 14 studies fell within the $95 \%$ confidence interval for FCM (1.8 to $4.6 \mathrm{~kg} / \mathrm{d}$ ) and DMI (-0.53 to $0.25 \mathrm{~kg} / \mathrm{d}$ ).

\section{DISCUSSION}

Publication bias is a potential concern in any review that combines data from multiple studies because studies with results that are significant, interesting, from large well-funded studies, or of higher quality are more likely to be published than studies without such characteristics (Wang and Bushman, 1999; Sutton et al., 2000). These published studies could represent a biased subset of the total number of studies and result in misleading or invalid conclusions (Wang and Bushman, 1999). Publication bias may be present to some degree in about $50 \%$ of reported meta-analyses but the effect of missing studies changed the conclusion less than $10 \%$ of the time and therefore may not be a major practical
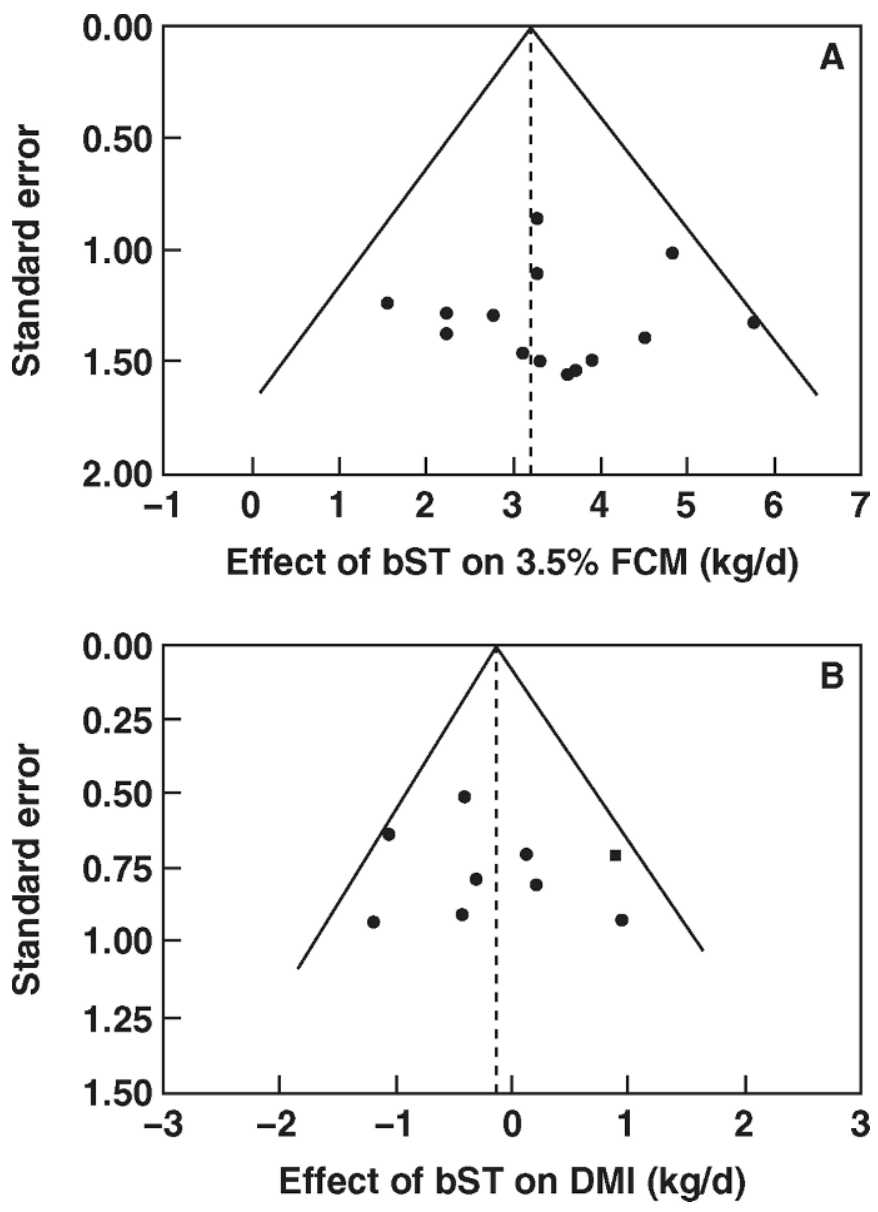

Figure 4. Funnel plot of the effect of bST on 3.5\% FCM $(\mathrm{A} ; \mathrm{n}=$ 14 studies) and DMI (B; $\mathrm{n}=9$ studies) against standard error. Points correspond to treatment effects from individual studies and diagonal lines indicate the expected 95\% confidence intervals around the summary estimate ( 1.8 to $4.6 \mathrm{~kg} / \mathrm{d}$ for FCM and -0.53 to $0.25 \mathrm{~kg} / \mathrm{d}$ for DMI). Administration of bST was initiated before 35 DIM and responses before 90 DIM evaluated. 
problem (Sutton et al., 2000). The FCM daily yield and DMI daily intake scatter plots (also called funnel plots) from our meta-analysis indicate that publication bias was not a major problem because all results fell within the respective 95\% confidence interval (Sterne and Egger, 2001).

Milk response to bST is generally considered to be negligible or at least reduced if administration is initiated before peak milk or before cows enter positive energy and nutrient balance (Chilliard, 1989; Bauman and Vernon, 1993; Etherton and Bauman, 1998). However, initiation of bST administration at 14 to $21 \mathrm{DIM}$ has increased milk yield by more than $3 \mathrm{~kg} / \mathrm{d}$ in several studies (Richard et al., 1985; Weber, 1997; Moallem et al., 2000; Carriquiry, 2006). Our meta-analysis of 14 studies detected a $3.2 \pm 0.7 \mathrm{~kg} / \mathrm{d}$ increase in FCM by multiparous cows before 90 DIM when bST administration was initiated before 35 DIM. This response is at the low end of the range ( 3 to $6 \mathrm{~kg}$ of FCM/d) reported for primiparous and multiparous cows injected after 60 DIM (Hartnell et al., 1991; Stanisiewski et al., 1994; Etherton and Bauman, 1998; Bauman et al., 1999) but the confidence intervals of these ranges overlap, which indicates that the response estimates do not differ.

Dohoo et al. (2003) conducted a meta-analysis of 19 studies (28 groups of cows) and determined an overall increase in $3.5 \% \mathrm{FCM}$ of $4.4 \mathrm{~kg} / \mathrm{d}$ (95\% confidence inter$\mathrm{val}=3.8$ to $5.0 \mathrm{~kg} / \mathrm{d}$ ) when cows were treated with $\mathrm{bST}$. Administration of bST increased 3.5\% FCM yield by $3.0 \mathrm{~kg} / \mathrm{d}(95 \%$ confidence interval $=1.7$ to $4.3 \mathrm{~kg} / \mathrm{d})$ in primiparous cows (6 groups, 5 studies) and by $4.4 \mathrm{~kg} /$ $\mathrm{d}(95 \%$ confidence interval $=3.7$ to $5.0 \mathrm{~kg} / \mathrm{d})$ in multiparous cows ( 7 groups, 6 studies). Administration of bST to the multiparous cows used in their meta-analysis was initiated before 35 DIM ( $\mathrm{n}=1$ study) and after 60 DIM ( $\mathrm{n}=5$ studies) and continued to near the end of lactation in all 6 studies (Dohoo et al., 2003). The milk response obtained in our meta-analysis of bST administration to cows in early lactation was at the low end of the ranges determined by Dohoo et al. (2003).

Several studies that initiated bST administration before 35 DIM were not included in our meta-analysis because they failed to meet other selection criteria for our analysis. A multi-site study of primiparous and multiparous cows indicated an FCM response of at least $4 \mathrm{~kg} / \mathrm{d}$ by 77 DIM when bST administration was initiated at 35 DIM (Chalupa et al., 1996). McGuffey et al. (1991) initiated bST administration at 28 to 45 DIM and detected an immediate FCM response of about $4 \mathrm{~kg} /$ $\mathrm{d}$. Results from other studies indicated that initiation of bST administration before 35 DIM increased FCM yield by 3 to $6 \mathrm{~kg} / \mathrm{d}$ before 70 DIM when cows were fed control diets with no effect (Lormore et al., 1990) or a decreased response (Austin et al., 1991) when dietary protein and energy content were increased. However, other studies (Elvinger et al., 1988; Zhao et al., 1992) detected little or no FCM response by 70 DIM when bST administration was initiated before 35 DIM. Moallem et al. (1999) initiated treatment at $10 \mathrm{DIM}$ and although they did not provide data to assess response before 90 DIM, they obtained an overall increase of $4.1 \mathrm{~kg}$ of FCM/d from 10 to 150 DIM.

Although FCM response to bST administration in early lactation is at the low end of the response obtained when bST administration is initiated later in lactation, the overall response of $3.2 \pm 0.7 \mathrm{~kg} / \mathrm{d}$ is not negligible. Initiation of bST administration before peak milk yield can increase peak milk and overall milk yield for the lactation (Chalupa et al., 1996; Moallem et al., 2000; Carriquiry, 2006). Because increased peak yield has been associated with greater milk yield for the lactation, bST-induced increases in peak milk yield might be expected to translate into greater milk yields than when bST administration is initiated later in lactation. However, the only apparent direct, complete-lactation evaluation of treatment initiation at 14 vs. 60 DIM (Stanisiewski et al., 1992) does not support this concept. Specific reasons for why milk response to bST administration in early lactation is less than in later lactation were not evaluated in this meta-analysis. One possible mechanism involves a reduced number of functional hepatic GHR and a reduction in circulating IGF-I (Radcliff et al., 2003). Insufficient dietary energy and nutrient supply can uncouple the ST-IGF axis (Vicini et al., 1991; McGuire et al., 1992) and can prolong the postpartum interval of reduced IGF-I (Radcliff et al., 2006). Although hepatic expression of GHR-1A can return to prepartum values by 21 DIM (Radcliff et al., 2006) and initiation of bST administration at 14 to 21 DIM can increase milk yield by more than $3 \mathrm{~kg} / \mathrm{d}$ in early lactation (Richard et al., 1985; Weber, 1997; Moallem et al., 2000; Carriquiry, 2006), factors that impede the postpartum increase in feed intake would be expected to reduce milk yield response to bST. Even if cows transition successfully from nonlactating and pregnant to nonpregnant and lactating and re-establish prepartum expression of GHR-1A, overall functional activity of other aspects of the ST signaling pathways could be attenuated by insufficient energy and nutrient supply (Beauloye et al., 2002) during the first part of lactation and limit the ability to respond to bST administration.

Our meta-analysis indicated that the increased FCM yield obtained before 90 DIM when bST administration was initiated before 35 DIM was the combined result of increased milk yield $(2.5 \mathrm{~kg} / \mathrm{d})$ and fat content $(0.31$ percentage units). This is consistent with the increase in milk fat that occurs when cows in negative EB are treated with bST but this transient response decreases 
as lactation progresses and cows enter positive EB (Peel and Bauman, 1987; Hartnell, et al., 1991). We only evaluated a relatively short treatment interval so the increased fat content of milk from bST-treated cows in our meta-analysis was not altered by length of treatment. Similar to results obtained when bST administration was initiated later in lactation (Bauman and Vernon, 1993; Etherton and Bauman, 1998), protein content of milk in our analysis was not modified by bST, and protein yield increased as a result of increased milk volume. Although small significant increases in milk fat and protein content were detected in the meta-analysis conducted by Dohoo et al. (2003), the authors concluded that the large among-study variation and small magnitude of these increases had no substantial or practical effect on the dairy industry.

Meta-analysis of the dose response studies $(n=6)$ indicated that FCM yields during early lactation increased curvilinearly as the dose of bST administered increased from 5 to $41.2 \mathrm{mg} / \mathrm{d}$. This hyperbolic doseresponse curve indicates a pattern of diminishing marginal returns as dose increased and is consistent with results from other dose-response studies (Hartnell, et al., 1991; Stanisiewski et al., 1994). The minimum and maximum effective doses ( 5 and $15 \mathrm{mg} / \mathrm{d}$, respectively) we determined for multiparous cows in early lactation were similar to those determined by Stanisiewski et al. (1994) for primiparous (5.0 and $16.7 \mathrm{mg} / \mathrm{d}$, respectively) and multiparous (2.0 and $16.6 \mathrm{mg} / \mathrm{d}$, respectively) cows treated daily with bST from about 75 DIM to the end of lactation.

When bST treatment is initiated after 60 DIM, milk yield peaks about $7 \mathrm{~d}$ later whereas DMI peaks some 4 to 8 wk after treatment initiation (Bauman, 1999). Dohoo et al. (2003) determined that DMI of bST-treated cows increased by approximately $1.5 \mathrm{~kg} / \mathrm{d}$ during the interval of treatment. Although our meta-analysis detected greater milk yield by bST-treated cows, DMI was not altered during the relatively short treatment interval ( 10 to $63 \mathrm{~d}, 49.6 \pm 3.6 \mathrm{~d}$ ). This lack of DMI response could be due to several factors (Allen, 2000; Ingvartsen and Andersen, 2000) including an insufficient treatment interval as studies have indicated that short-term administration of bST does not affect feed intake (Peel and Bauman, 1987). In addition, studies in our meta-analysis evaluated effects of bST on DMI during an interval (early lactation) when cows typically increase their DMI. These concurrent increases and their associated standard errors may have reduced the ability to detect differences in DMI. The specific mechanism(s) by which bST affects DMI has not been elucidated but it is possible that the combined effects of all postpartum satiety signals are greater than those elicited by bST administration. These factors likely con- tributed to minimize or mask any effect of bST on early postpartum DMI and might explain why increased milk yield was not accompanied by an increase in DMI in our meta-analysis.

Despite the increased FCM yield without a concurrent increase in DMI, our meta-analysis indicated no effect of bST on change in BW during early lactation. Body weight change in early lactation correlates poorly with energy status and may not reflect true change in stores of tissue energy (NRC, 2001; Schröder and Staufenbiel, 2006). Body condition score (NRC, 2001) and backfat thickness (Schröder and Staufenbiel, 2006) also have limitations but have been suggested as measurements that provide a more independent and precise prediction of tissue mobilization or storage of energy than BW. However, only a few $(n<5)$ of the studies in this meta-analysis reported BCS or backfat thickness, so these measures were not subjected to meta-analysis. Dohoo et al. (2003) estimated that the effect of more than $200 \mathrm{~d}$ of bST administration on BCS was a reduction of approximately 0.2 units on a 5-point scale.

Although no effect of bST on change in BW was detected, initiation of bST administration before 35 DIM decreased EB before 90 DIM. These results indicate that increased milk yield was supported at least in part by mobilization of body reserves. Initiation of bST administration in early lactation appears to have little impact on the moment or magnitude of the EB nadir (Weber, 1997; Moallem et al., 2000; Carriquiry, 2006). The overall decreased EB of cows treated with bST in early lactation appears to be caused primarily by a prolonged duration of negative EB. These results support the concept that replenishment of tissue mobilized in early lactation is initiated later in lactation in the bST-treated cow because of an extended period during which milk yield has a greater priority than body tissue for energy and nutrients. This is supported by the lack of effect of supplemental dietary fat on EB as the bSTtreated cow continued to partition nutrients and energy toward milk synthesis. This concept has prompted consideration of the need to alter management by extended lactation or delayed breeding to provide sufficient time for bST-treated cows to replenish mobilized body reserves.

\section{CONCLUSIONS}

This meta-analysis of 14 studies indicated that initiation of bST administration to multiparous Holsteins before 35 DIM increased $3.5 \%$ FCM by $3.2 \pm 0.7 \mathrm{~kg} / \mathrm{d}$ before $90 \mathrm{DIM}$. This early lactation response is at the low end of the 3 to $6 \mathrm{~kg} / \mathrm{d}$ response typically observed when bST administration is initiated according to label (wk 9 of lactation). This increase in FCM yield was 
achieved through increased milk yield and milk fat content. Duration of negative EB during the first 70 to 90 DIM was prolonged and overall EB reduced when cows were treated with bST. Inclusion of supplemental dietary fat did not improve the energy status of cows by 90 DIM. Similar to when bST administration is initiated during the ninth week of lactation, initiation of bST treatment before 35 DIM causes the cow to partition nutrients and energy toward milk synthesis for a longer duration and likely requires that the cow be provided a longer interval to replenish body reserves relative to cows not treated with bST.

\section{REFERENCES}

Allen, M. S. 2000. Effects of diet on short-term regulation of feed intake by lactating dairy cattle. J. Dairy Sci. 83:1598-1624.

Austin, C. L., D. J. Schingoethe, D. P. Casper, and R. M. Cleale. 1991. Influence of bovine somatotropin and nutrition on production and composition of milk from dairy cows. J. Dairy Sci. 74:3920-3932.

Bauman, D. E. 1999. Bovine somatotropin and lactation: From basic science to commercial application. Domest. Anim. Endocrinol. $17: 101-116$.

Bauman, D. E., R. W. Everett, W. H. Weiland, and R. J. Collier. 1999. Production responses to bovine somatotropin in northeast dairy herds. J. Dairy Sci. 82:2564-2573.

Bauman, D. E., D. L. Hard, B. A. Crooker, M. S. Partridge, K. Garrick, L. D. Sandles, E. N. Hollis, S. E. Franson, G. F. Hartnell, and R. L. Hintz. 1989. Long-term evaluation of a prolonged-release formulation of n-methionyl bovine somatotropin in lactating dairy cows. J. Dairy Sci. 72:642-651.

Bauman, D. E., and R. G. Vernon. 1993. Effects of exogenous bovine somatotropin on lactation. Annu. Rev. Nutr. 13:437-461.

Beauloye, V., B. Willems, V. de Coninck, S. J. Frank, M. Edery, and J. P. Thissen. 2002. Impairment of liver GH receptor signaling by fasting. Endocrinology 143:792-800.

Bell, A. W., and D. E. Bauman. 1997. Adaptations of glucose metabolism during pregnancy and lactation. J. Mammary Gland Biol. Neoplasia 2:265-278.

Burton, J. H., G. K. MacLeod, B. W. McBride, J. L. Burton, K. Bateman, I. McMillan, and R. G. Eggert. 1990. Overall efficacy of chronically administered recombinant bovine somatotropin to lactating dairy cows. J. Dairy Sci. 73:2157-2167.

Carriquiry, M. 2006. Dietary fat and bovine somatotropin (bST) initiated in early lactation in dairy cows. PhD Thesis. University of Minnesota, St. Paul.

Chalupa, W., B. Vecchiarelli, D. T. Galligan, J. D. Ferguson, L. S. Baird, R. W. Hemken, R. J. Harmon, C. G. Soderholm, D. E. Otterby, R. J. Annexstad, J. G. Linn, W. P. Hansen, F. R. Ehle, D. L. Palmquist, and R. G. Eggert. 1996. Responses of dairy cows supplemented with somatotropin during weeks 5 through 43 of lactation. J. Dairy Sci. 79:800-812.

Chilliard, Y. 1989. Long term effects of recombinant bovine somatotropin (rBST) on dairy cow performances: A review. Pages 6187 in Use of Somatotropin in Livestock Production. K. Sejrsen, M. Vestergaard, and A. Neimann-Sorensen, ed. Elsevier Applied Science, New York, NY.

Cohick, W. S. 1998. Role of the insulin-like growth factors and their binding proteins in lactation. J. Dairy Sci. 81:1769-1777.

Collier, R. J., J. C. Byatt, S. C. Denham, P. J. Eppard, A. C. Fabellar, R. L. Hintz, M. F. McGrath, C. L. McLaughlin, J. K. Shearer, J. J. Veenhuizen, and J. L. Vicini. 2001. Effects of sustained release bovine somatotropin (sometribove) on animal health in commercial dairy herds. J. Dairy Sci. 84:1098-1108.

de Boer, G., P. H. Robinson, and J. J. Kennelly. 1991. Hormonal responses to bovine somatotropin and dietary protein in early lactation dairy cows. J. Dairy Sci. 74:2623-2632.
Dohoo, I. R., K. Leslie, L. DesCôteaux, A. Fredeen, P. Dowling, A. Preston, and W. Shewfelt. 2003. A meta-analysis review of the effects of recombinant bovine somatotropin. 1. Methodology and effects on production. Can. J. Vet. Res. 67:241-251.

Elvinger, F., H. H. Head, C. J. Wilcox, R. P. Natzke, and R. G. Eggert. 1988. Effects of administration of bovine somatotropin on milk yield and composition. J. Dairy Sci. 71:1515-1525.

Eppard, P. J., S. Hudson, W. J. Cole, R. L. Hintz, G. F. Hartnell, T. W. Hunter, L. E. Metzger, A. R. Torkelson, B. G. Hammond, R. J. Collier, and G. M. Lanza. 1991. Response of dairy cows to high doses of a sustained-release bovine somatotropin administered during two lactations. 1. Production response. J. Dairy Sci. 74:3807-3821.

Etherton, T. D., and D. E. Bauman. 1998. Biology of somatotropin in growth and lactation of domestic animals. Physiol. Rev. 78:745-761.

Hansen, W. P., D. E. Otterby, J. G. Linn, J. F. Anderson, and R. G. Eggert. 1994. Multi-farm use of bovine somatotropin for two consecutive lactations and its effects on lactational performance, health, and reproduction. J. Dairy Sci. 77:94-110.

Hartnell, G. F., S. E. Franson, D. E. Bauman, H. H. Head, J. T. Huber, R. C. Lamb, K. S. Madsen, W. J. Cole, and R. L. Hintz. 1991. Evaluation of sometribove in a prolonged-release system in lactating dairy cows-Production responses. J. Dairy Sci. 74:2645-2663.

Ingvartsen, K. L., and J. B. Andersen. 2000. Integration of metabolism and intake regulation: A review focusing on periparturient animals. J. Dairy Sci. 83:1573-1597.

Lormore, M. J., L. D. Muller, D. R. Deaver, and L. C. Griel Jr. 1990. Early lactation responses of dairy cows administered bovine somatotropin and fed diets high in energy and protein. J. Dairy Sci. 73:3237-3247.

McBride, B. W., J. L. Burton, J. P. Gibson, J. H. Burton, and R. G. Eggert. 1990. Use of recombinant bovine somatotropin for up to two consecutive lactations on dairy production traits. J. Dairy Sci. 73:3248-3257.

McGuffey, R. K., R. P. Basson, D. L. Snyder, E. Block, J. H. Harrison, A. H. Rakes, R. S. Emery, and L. D. Muller. 1991. Effect of somidobove sustained release administration on the lactation performance of dairy cows. J. Dairy Sci. 74:1263-1276.

McGuire, M. A., D. E. Bauman, M. A. Miller, and G. F. Hartnell. 1992. Response of somatomedins (IGF-I and IGF-II) in lactating cows to variations in dietary energy and protein and treatment with recombinant-methionyl bovine somatotropin. J. Nutr. 122:128-136.

Moallem, U., Y. Folman, A. Bor, A. Arav, and D. Sklan. 1999. Effect of calcium soaps of fatty acids and administration of somatotropin on milk production, preovulatory follicular development, and plasma and follicular fluid lipid composition in high yielding dairy cows. J. Dairy Sci. 82:2358-2368.

Moallem, U., Y. Folman, and D. Sklan. 2000. Effects of somatotropin and dietary calcium soaps of fatty acids in early lactation on milk production, dry matter intake, and energy balance of highyielding dairy cows. J. Dairy Sci. 83:2085-2094.

Moallem, U., M. Kaim, Y. Folman, and D. Sklan. 1997. Effect of calcium soaps of fatty acids and administration of somatotropin in early lactation on productive and reproductive performance of high producing dairy cows. J. Dairy Sci. 80:2127-2136.

NRC. 2001. Nutrient Requirements of Dairy Cattle. 7th ed. National Academy Press, Washington, DC.

Normand, S. L. T. 1999. Meta-analysis: Formulating, evaluating, combining, and reporting. Stat. Med. 18:321-359.

Peel, C. J., and D. E. Bauman. 1987. Somatotropin and lactation. J. Dairy Sci. 70:474-486.

Radcliff, R. P., B. L. McCormack, B. A. Crooker, and M. C. Lucy. 2003. Growth hormone (GH) binding and expression of $\mathrm{GH}$ receptor $1 \mathrm{~A}$ mRNA in hepatic tissue of periparturient dairy cows. J. Dairy Sci. 86:3933-3940.

Radcliff, R. P., B. L. McCormack, D. H. Keisler, B. A. Crooker, and M. C. Lucy. 2006. Partial feed restriction decreases growth hormone receptor 1A mRNA expression in postpartum dairy cows. J. Dairy Sci. 89:611-619. 
Richard, A. L., S. N. McCutcheon, and D. E. Bauman. 1985. Responses of dairy cows to exogenous bovine growth hormone administered during early lactation. J. Dairy Sci. 68:2385-2389.

Santos, J. E. P., J. T. Huber, C. B. Theurer, L. G. Nussio, C. B. Nussio, M. Tarazon, and R. O. Lima-Filho. 1999. Performance and nutrient digestibility by dairy cows treated with bovine somatotropin and fed diets with steam-flaked sorghum or steam-rolled corn during early lactation. J. Dairy Sci. 82:404-411.

SAS Institute. 2001. SAS User's Guide: Statistics. SAS Inst. Inc., Cary, NC.

Schneider, P. L., D. Sklan, D. S. Kronfeld, and W. Chalupa. 1990. Responses of dairy cows in early lactation to bovine somatotropin and ruminally inert fat. J. Dairy Sci. 73:1263-1268.

Schröder, U. J., and R. Staufenbiel. 2006. Invited review: Methods to determine body fat reserves in the dairy cows with special regard to ultrasonographic measurement of backfat thickess. J. Dairy Sci. 89:1-14.

St-Pierre, N. R. 2001. Integrating quantitative findings from multiple studies using mixed model methodology. J. Dairy Sci. 84:741-755.

Stanisiewski, E. P., L. F. Krabill, and J. W. Lauderdale. 1992. Milk yield, health, and reproduction of dairy cows given somatotropin (Somavubove) beginning early postpartum. J. Dairy Sci. 75:2149-2164.
Stanisiewski, E. P., J. F. McAllister, K. A. Ash, V. N. Taylor, D. D. Kratzer, and J. W. Lauderdale. 1994. Production performance of dairy cattle administered recombinantly derived bovine somatotropin (USAN, SOMAVUBOVE) daily: A dose range study. Domest. Anim. Endocrinol. 11:239-260.

Sterne, J. A., and M. Egger. 2001. Funnel plots for detecting bias in meta-analysis: Guidelines on choice of axis. J. Clin. Epidemiol. 54:1046-1055.

Sutton, A. J., S. J. Duval, R. L. Tweedie, K. R. Abrams, and D. R. Jones. 2000. Empirical assessment of effect of publication bias on meta-analyses. BMJ 320:1574-1577.

Vicini, J. L., F. C. Buonomo, J. J. Veenhuizen, M. A. Miller, D. R. Clemmons, and R. J. Collier. 1991. Nutrient balance and stage of lactation affect responses of insulin, insulin-like growth factors I and II, and insulin-like growth factor-binding protein 2 to somatotropin administration in dairy cows. J. Nutr. 121:1656-1664.

Wang, M. C., and B. J. Bushman. 1999. Integrating results through meta-analytical review using SAS software. SAS Institute, Cary, NC.

Weber, W. J. 1997 Effect of bovine somatotropin and supplemental dietary fat on lactational performance of Holstein cows. MS Thesis. Univ. Minnesota.

Zhao, X., J. H. Burton, and B. W. McBride. 1992. Lactation, health, and reproduction of dairy cows receiving daily injectable or sustained release. J. Dairy Sci. 75:3122-3130. 